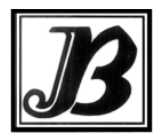

J. Bio-Sci. 25: 27-37, 2017

ISSN 1023-8654

http://www.banglajol.info/index.php/JBS/index

\title{
STUDIES ON ANTIOXIDANT POTENTIAL, PHYTOCHEMICAL PROPERTIES AND TOXICITY OF FOUR POPULAR MEDICINAL PLANTS OF BANGLADESH
}

\author{
N Rashid, AA Paul, S Islam, SA Sajib, K Nasirujjaman, KMF Hoque and MA Reza* \\ Molecular Biology and Protein Science Laboratory, Department of Genetic Engineering and Biotechnology, \\ University of Rajshahi, Bangladesh
}

\begin{abstract}
Medicinal plant extract has long been used successfully in 'unani' or 'ayurvedic' medicine. Medicinal plant extract contains bioactive molecules and activity of these molecules may help to mitigate, eradicate or cure diseases. In the advent for the search for new medicinally important bioactive molecule, the current paper deals with the anti-oxidative, cytotoxic and phytochemical analysis of Scoparia dulcis leaf and root, Curculigo orchioides root, Pandanus fascicularis root and Baccaurea sapida leaf extract. Aqueous and methanolic extracts were made for each of the extracts where they posses significant antioxidative properties. High activities were seen in $P$. fascicularis and S. dulcis plant extract where IC50 values were $21.87 \mu \mathrm{g} / \mathrm{ml}$ and $173.36 \mu \mathrm{g} / \mathrm{ml}$ respectively. In toxicity test, only $P$. fascicularis extracts showed lethality in a dose-dependent manner where the LD50 value was 25.64 $\mu \mathrm{g} / \mathrm{ml}$. By the phytochemical analysis, it was found that each of these plant species possesses glycosides, protein, carbohydrates, alkaloid, flavonoid etc. which are pharmacologically active biomolecules. These important properties of those plants showed an indication that these plants can further be tested for the utilization in therapeutic purpose or in cosmetic industry.
\end{abstract}

Key words: Antioxidant, cytotoxicity, extracts, phytochemicals, plant

\section{Introduction}

A medicinal plant is a plant that is used in maintaining health, to be administered for a specific condition or both whether in modern or in traditional medicine (Smith-Hall et al. 2012, Ahn 2017). Plants have been utilized as medicines for thousands of years (Samuelsson 2009). These medicines initially took the form of crude drugs such as tinctures, teas, poultices, powders, and other herbal formulations (Balick and Cox 1996). However, with the advent of chemically or artificially synthesized drugs, these medicinal plants as herbal formulations declined popularity day by day. But the consequence of severe side effects of the synthetic drugs, modern drug discovery is retuning towards the nature and medicinal plants serve as gold mine for bioactive lead drug molecule (Rates 2001). Medicinal plants have been the single most productive source of leads for the development of drugs. A statistics shows that in recent years there were over a 100 new products in clinical development, particularly as anti-cancer and anti-infective agents (Harvey 2008). According to WHO, there are 21,000 medicinal plants possessing potentiality that can be used to reduce the human disease (WHO 2000).

\footnotetext{
*Author for correspondence: reza.gen@ru.ac.bd
} 
In Bangladesh, more than 500 plants have so far been enlisted as medicinal plant (Ghani 1998, Nishat et al. 2002). Around 400 government nursery and some private organization produce and sale medicinal plants and plant based products in Bangladesh. As the demand of medicinal plants and plant based products are increasing day by day; their cultivation has been started in different district in our country. A great example of this exploration is "Natore Owshodhi gram". This village is located at the Laxmipur Kholabaria Union under the Natore sadar upazilla District. Farmers of this village and nearby villages cultivate several medicinally important plant species as cash crops (Sharmin 2004). Despite the medicinal value of these plants very few studies were conducted regarding their phytochemical properties, antioxident potential and cytotoxicity. Therefore, in the present study antioxidant potential, phytochemical properties and cytotoxic activity were examined for Scoparia dulcis leaf and root, Curculigo orchioides root, Pandanus fascicularis root and Baccaurea sapida leaf. As the four medicinally important plant species are the major focus paper, it will be rationale to provide a brief description of these plants below:

\section{Baccaurea sapida}

B. Sapida (Latkan) is a delicious fruit normally grown in Bangladesh, Nepal, India, Myanmar, China, Thailand and Peninsular Malaysia (Alam 2004). Latkan fruits are yellow, velvety, 2-3 cm in diameter with leathery pericarp. Seeds are arrilus, three in number, embedded in pale rose colored delicious pulp. B. sapida fruits are used as food and in treatment of bacterial infectious diseases such as diarrhea, dysentery, skin infection (Jain 1986, Mann et al. 2008, Deb and Bhowmick 2013)

\section{Pandanus fascicularis}

Pandanus roots are used in unani and other folk medicine. Roots, leaves, fruits etc are used as anthelmintic, tonic, in treatment of liver disorders (Jothimani et al. 2011). Root extract also have anti-inflammatory and analgesic activity. In treatment of diabetes, Pandanus roots are used. Roots are widely used in treatment of osteoarthritis and skin diseases like leprosy. In the Ayurvedic system of medicine, the roots of $P$. fascicularis are used in 'Prameha' and employed for their hypoglycemic action (Madhavan et al. 2008, Ayyanar and Ignacimuthu 2011, Jothimni et al. 2012).

\section{Curculigo orchioides}

This plant is endangered species and it is native to Indian sub-continent including Bangladesh. This plant contains curculigoside A, B, C and D and curculigine A and D can also be found. This plant is used for diseases of the urogenital system in both males and females (Chauhan et al. 2007). It is also prescribed in treatment of piles, jaundice, gonorrhea, asthma, and diarrhea (Chauhan et al. 2010). This plant extract is present in several herbal formulations for gynecological problems and sexual weakness of males (Duraipandiyan et al. 2006).

\section{Scoparia dulcis}

S. dulcis is a weed in many parts of Bangladesh but its use as traditional medicine has led to overexploitation of this plant (Mollik et al. 2010). Scoparinol, scoparic acid, scopadulcic acid, scopadulciol, and scopadulin have been isolated from this plant. This plant is used for diabetes, hypertension and other health conditions such as hemorrhoids, anemia, burns, and headaches (Edeoga et al. 2006). 


\section{Materials and Methods}

\section{Collection of plant material}

Roots of $P$. fascicularis, $C$. orchioides and leaves of $S$.dulcis were collected from the Natore Owsodhi gram. Leaves of $B$. Sapida were obtained from Narshingdi where this plant is cultivated in commercial level.

\section{Extraction of phytochemicals}

For the extraction of phytochemicals, the leaf and root of the selected plants were dried at room temperature and was crushed into powder by electric blender (Pant et al. 2017). For methanolic extraction, powders were extracted in methanol apparatus at $55-85^{\circ} \mathrm{C}$ for $12-24 \mathrm{~h}$. The extracts obtained were then dried using rotavapor drier at $55-85^{\circ} \mathrm{C}$, and the solid extracts were preserved in refrigerator for further analysis. For aqueous extraction powders were dissolved in $\mathrm{dH}_{2} \mathrm{O}$ and centrifuged at $8000 \mathrm{rpm}$ for $10 \mathrm{~min}$ at room temperature and supernatant served as crude aqueous extract.

\section{In vitro antioxidant assay}

In order to examine the antioxidant properties of methanolic extracts of the test plants explants, DPPH free radical scavenging assay (Hatano et al. 1988) was employed. DPPH antioxidant assay is based on the ability of 1, 1 diphenyl-2-picryl-hydrazyl (DPPH) a stable free radical, to decolorize in the presence of antioxidants. The percentage (\%) inhibition activity was calculated from the following equation

$$
\% l=\left\{\left(A_{0}-A_{1}\right) / A_{0}\right\} \times 100
$$

Where,

$A_{0}$ is the absorbance of the control, and

$A_{1}$ is the absorbance of the extract/standard.

Then $\%$ inhibitions were plotted against log concentration and from the graph $I C_{50}$ was calculated. Extracts (30 mg) of four plant samples were taken in four $1.5 \mathrm{ml}$ centrifuge tube. Methanol $(1 \mathrm{ml})$ was added to each of the tubes with the help of micropipette. Then the tubes were vortexed for 2-3 min so that plant extracts could mix with methanol. Subsequently, tubes were centrifuged at $10000 \mathrm{rpm}$ for 5 minutes. Methanol (1.5 $\mathrm{ml}$ ) solution and DPPH solution $(1.5 \mathrm{ml})$ was then added in glass test tubes. Each test tube contained different concentrations of extract solutions ( $50 \mu \mathrm{g} / \mathrm{ml}, 100 \mu \mathrm{g} / \mathrm{ml}, 200 \mu \mathrm{g} / \mathrm{ml}$, and $400 \mu \mathrm{g} / \mathrm{ml})$. The negative control contained only methanol and DPPH solution, in contrast the positive control contained Ascorbic acid standard with methanol and DPPH was added. All the test tubes were incubated at room temperature for 30 min in dark chamber to complete the reaction. Finally, the absorbance of the solutions was measured at 517 $\mathrm{nm}$ wavelength using spectrophotometer.

\section{Phytochemical properties}

Phytochemical analysis was conducted using standard protocols (Obadoni and Ochuko 2002, Senguttuvan et al. 2014, Pant et al. 2017). Plants extracts were screened for glycosides, protein, carbohydrates, alkaloids, tannin, phlobatannin, flavonoid, steroids, saponins, phenolic compound, phytosterols, fats and for anthraquinones.

\section{Fehling's test for glycosides}

A small amount of grinded plant sample was taken and dissolved in water. Fehling's solution was added in test tube containing water dissolved plant crude extracts. Brick-red precipitation formation indicated the 
presence of glycosides in the plant sample. In another test grinded plant sample was dissolved in methanol and few drops diluted $\mathrm{H}_{2} \mathrm{SO}_{4}$ was added. Then test tubes were boiled after adding $\mathrm{NaOH}$ solution for neutralization. Brick-red precipitation indicated the presence of glycocides.

\section{General test for glycosides}

Small amount of grinded plant sample was dissolved in water and a small portion of aqueous $\mathrm{NaOH}$ solution was added. A yellow color formation was considered the indicative of the presence of glycosides.

\section{Biuret test for protein}

First Biuret reagent was prepared according to Gornall et al. (1949). Few drops of Biuret reagent were added in four test tubes which containing different crude extracts. Upon completion of the reaction deep purple/lilac color formation confirms the presence of protein.

\section{Benedict's test for simple carbohydrates}

Different grinded plant sample $(1 \mathrm{gm})$ was dissolved in water $(10 \mathrm{ml})$ and filtered using Whatman 1 filter paper. From the stock solution, $5 \mathrm{ml}$ were taken to other test tubes and added $5 \mathrm{ml}$ Benedict reagent (Benedict 1909).Tubes were heated on to the boiling water bath for few minutes. A color change indicated the presence of simple carbohydrate.

\section{Hager's reagent for alkaloid test}

A few amount of water solution of different plant samples were neutralized by adding diluted $\mathrm{H}_{2} \mathrm{SO}_{4}$ in few drops. The solution was then treated with a small amount of Hager's reagent. The presence of alkaloid was confirmed by the formation of yellow crystals.

\section{Ferric chloride test for tannin}

Water and methanolic extracts of four plant samples were stirred in $\mathrm{dH}_{2} \mathrm{O}$. Then $5 \% \mathrm{FeCl}_{3}$ solution was added in tubes. The presence of tannin was confirmed by the colored (blue, green, blue-black) precipitation.

\section{Test for phlobatannin}

$5 \mathrm{ml}$ of aqueous and methanolic solution of four plant extracts taken and added diluted $\mathrm{HCl}$. The presence of phlobatannin was confirmed by red or reddish color precipitation formation.

\section{$\mathrm{HCl}$ test for flavonoid}

Aqueous and methanolic solutions of plants extracts were taken and concentrated $\mathrm{HCl}$ were added from the side of the test tubes. Presence of flavonoid is indicated by red color formation.

\section{Salkowski's test for steroids}

Aqueous solution $(5 \mathrm{ml})$ of extracts were taken in test-tubes and chloroform $(3 \mathrm{ml})$ and concentrated $\mathrm{H}_{2} \mathrm{SO}_{4}$ $(2 \mathrm{ml})$ were added from the side of the test tubes. Red color production in the chloroform layer is the confirmation of presence steroids.

\section{Frothing test for saponine}

Solution ( $5 \mathrm{ml}$ ) of crude aqueous extracts of different plant samples was shaken strongly in a test tube. Produced of frothing and persistence of the froth upon warming for 2-3 minutes can be taken as a primary confirmation for saponine presence. 


\section{Test for phenolic compound}

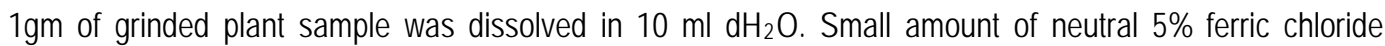
solution was added to it in test tubes. Presence of phenolic compounds in the sample was detected based on the formation of a dark green color.

\section{Test for phytosterols}

$0.5 \mathrm{gm}$ grind sample was dissolved in acetic anhydride solution $(2 \mathrm{ml})$. Few drops of concentrated $\mathrm{H}_{2} \mathrm{SO}_{4}$ was added very slowly by the side of the test tubes. A change in color detects the presence of phytosterols.

\section{Ethanol emulsion test for fats}

Solution $(5 \mathrm{ml})$ of plant extracts was taken in different test tubes. Ethanol $(2 \mathrm{ml})$ were added to each test tube

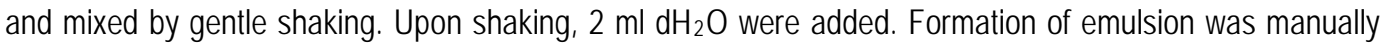
visualized to detect the presence of fat.

\section{Test for anthrquinones}

Powder (1 gm) of grinded plant sample was taken in different test tubes. Chloroform ( $5 \mathrm{ml})$ was added to each of the tubes and kept on boiling water bath for 5 min. After 5 minutes of boiling, remaining solutions were filtered and cooled at room temperature. Subsequently, $10 \%$ ammonia solution $(5 \mathrm{ml}$ of) was added to the filtrate. The tubes were shaken to visualize the formation of bright pink color as the indicator of the presence of Anthraquinones.

\section{Toxicity assay}

Brine Shrimp lethality assay was performed using the method of Meyer et al. (1982) with Artemia salina (nauplii) (24 hr post hatching). Ten organisms were used for each concentration. Different concentrations of solutions were prepared using different plant extracts and dose concentration was $5 \mu \mathrm{g} / \mathrm{ml}, 10 \mu \mathrm{g} / \mathrm{ml}, 15$ $\mu \mathrm{g} / \mathrm{ml}, 20 \mu \mathrm{g} / \mathrm{ml}$ and $25 \mu \mathrm{g} / \mathrm{ml}$, respectively. Reading for lethality of the nauplii was obtained after 24 hours of given doses. Percentage (\%) of inhibition was calculated by comparing four samples with the control samples which do not contain any plant extract.

\section{Results and Discussion}

\section{Antioxidant potential}

In the present study, the antioxidant activity of the plant extracts of B. sapida, P. fascicularis, C. orchioides and $S$. dulcis were evaluated by DPPH free radical scavenging assay. The antioxidant activity was increased by increasing the concentration of the extract in a dose dependent manner. Different concentrations of the sample extracts viz. $50 \mu \mathrm{g} / \mathrm{ml}, 100 \mu \mathrm{g} / \mathrm{ml}, 200 \mu \mathrm{g} / \mathrm{ml}$ and $400 \mu \mathrm{g} / \mathrm{ml}$ were used in the experiment. B. sapida extracts showed the scavenging value of $12.90 \%, 30.74 \%, 44.59 \%$, and $57.31 \%$ respectively in four different concentration with a $\mathrm{IC}_{50}$ value of $302.16 \mu \mathrm{g} / \mathrm{ml}$ which means moderate free-radical scavenging activity are shown by this plant extracts. However, high antioxidant activity was observed in case of $P$. fascicularis extracts with $\mathrm{IC}_{50}$ value of $121.87 \mu \mathrm{g} / \mathrm{ml}$. The scavenging value of the extracts were $62.57 \%, 66.16 \%$, $67.30 \%, 69.75 \%$ respectively in four different concentrations mentioned above. $4.14 \%, 13.91 \%, 31.77 \%$ and $58.65 \%$ of scavenging value was obtained for $C$. orchioides extracts in $50 \mu \mathrm{g} / \mathrm{ml}, 100 \mu \mathrm{g} / \mathrm{ml}$, and $200 \mu \mathrm{g} / \mathrm{ml}$ 
and $400 \mu \mathrm{g} / \mathrm{ml}$ concentrations, respectively. The calculated $I_{50}$ value of $C$. orchioides extract was 336.98 $\mu \mathrm{g} / \mathrm{ml}$. In case of $S$. dulcis extracts scavenging value of $35.18 \%, 63.67 \%, 65.97 \%, 69.02 \%$ respectively were obtained. S. dulcis root extracts showed a higher free-radical scavenging activity and the $\mathrm{IC}_{50}$ value was $173.36 \mu \mathrm{g} / \mathrm{ml}$. Antioxidant potentiality of each of the extract was compared with the standard ascorbic acid. The results of DPPH radical scavenging assays of ascorbic acid (standard) and our four plant extracts are given in Table 1 and in the Figs 1 and 2.
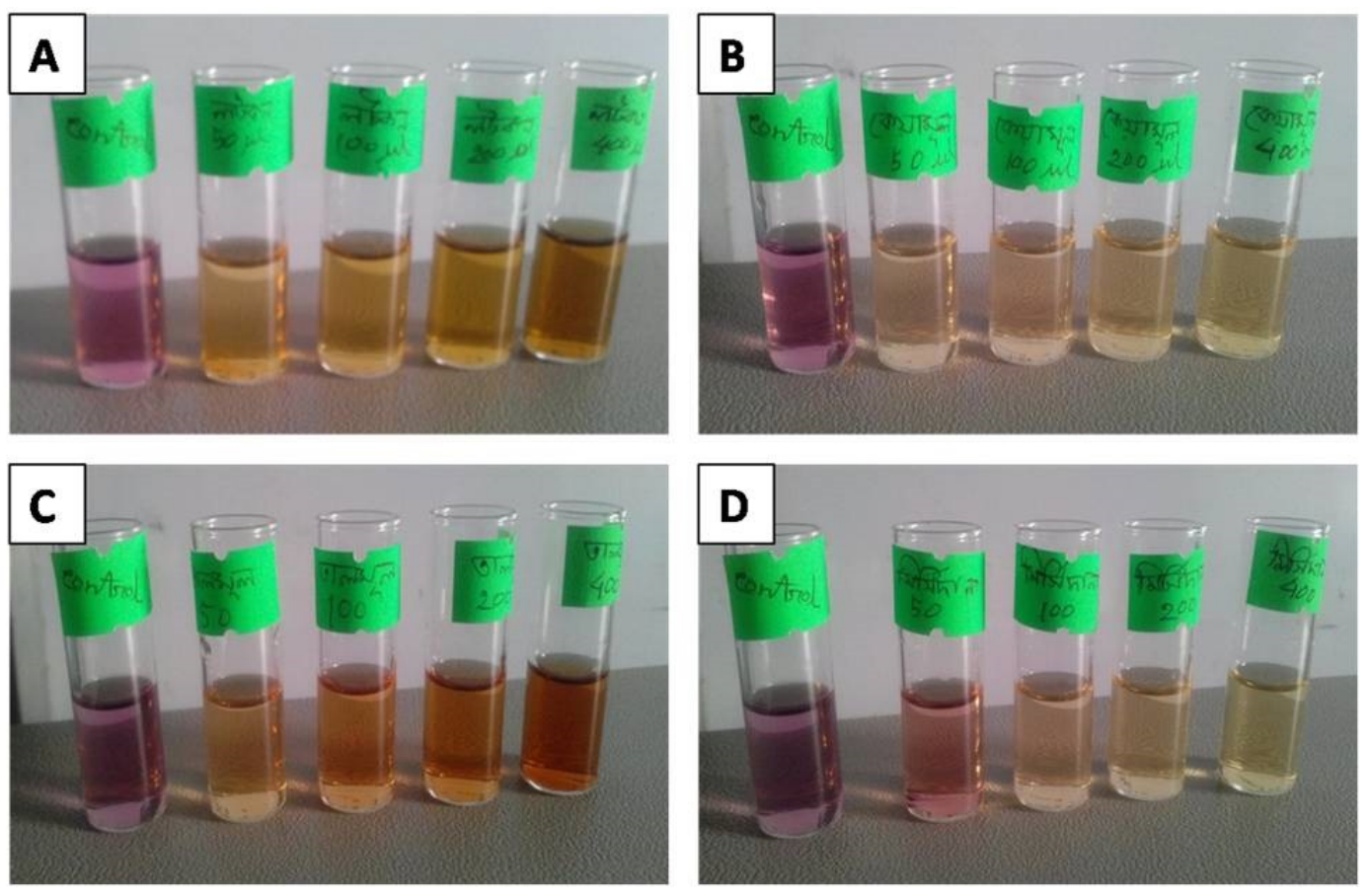

Fig.1. Decolorization of DPPH solution by (A) B. sapida extracts, (B) P. fascicularis extracts, (C) C.orchioides extracts and (D) C. orchioides extracts.

Table 1. Percentage (\%) of scavenging by DPPH free radical scavenging assay of four (4) different plant sample extract along with the standard ascorbic acid.

\begin{tabular}{lccccc}
\hline $\begin{array}{l}\text { Concentrations } \\
(\mu \mathrm{g} / \mathrm{ml})\end{array}$ & \multicolumn{5}{c}{ \% of scavenging } \\
\cline { 2 - 6 } & Ascorbic acid & B. sapida (leaf) & P. fascicularis (root) & C. orchioides (root) & S. dulcis (leaf) \\
\hline 0 & 0 & 0 & 0 & 0 & 0 \\
50 & 68.59 & 12.90 & 62.57 & 4.14 & 35.18 \\
100 & 72.64 & 30.74 & 66.16 & 13.91 & 63.67 \\
200 & 77.45 & 44.59 & 67.30 & 31.77 & 65.97 \\
400 & 78.23 & 57.31 & 69.75 & 58.65 & 69.02 \\
\hline
\end{tabular}



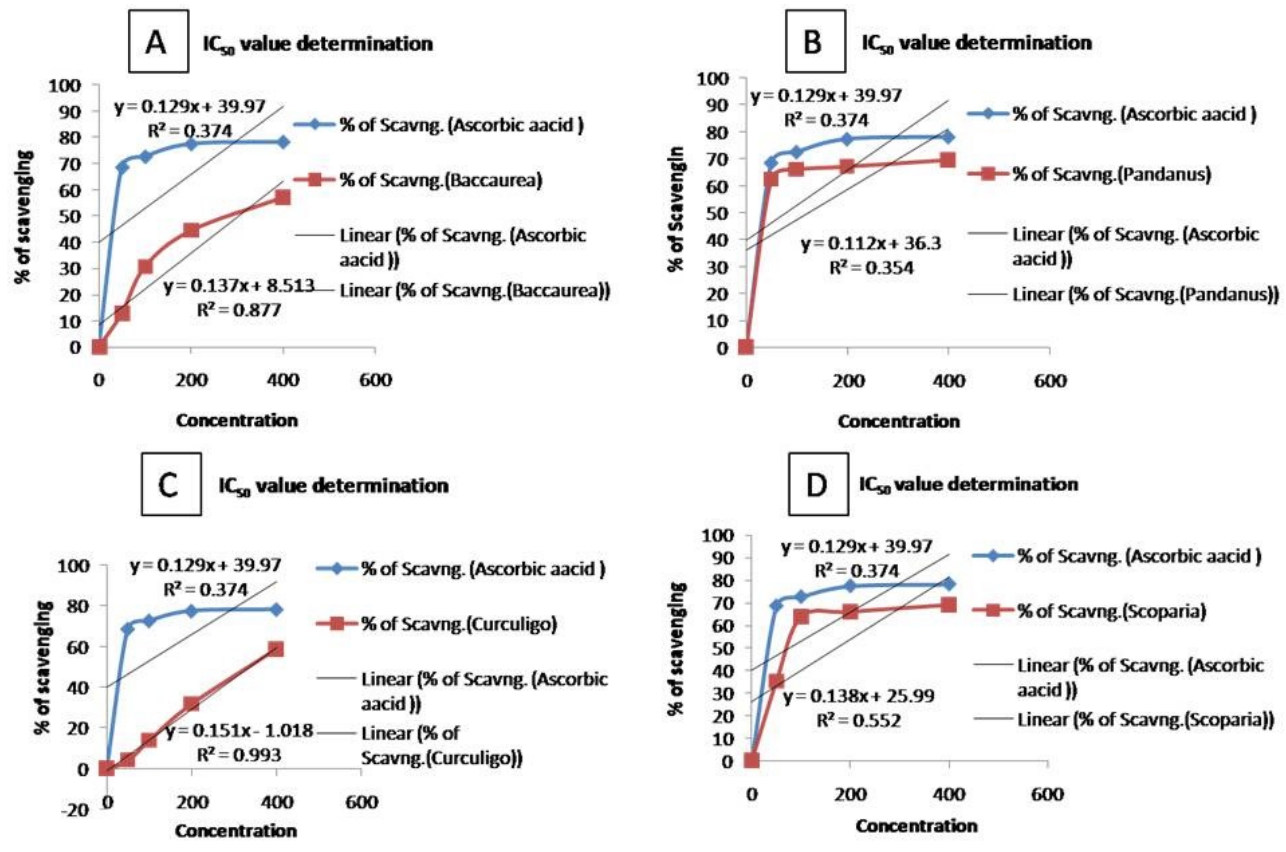

Fig. 2. DPPH free radical scavenging activity of the plant extracts at different concentrations along with ascorbic acid standard $(\mu \mathrm{g} / \mathrm{ml})($ A). B. sapida leaf extract, (B). P. fascicularis root extract, (C).C. orchioides root extract, and (D). S. dulciss.

\section{Phytochemical properties of four plant extracts}

14 phytochemical properties of medicinally important four plant extracts were investigated in the present study and the results of the study are summarized in the Table 2.

\section{Toxicity test of four plant extracts}

Brine-shrimp lethality bioassay was conducted at five different concentrations $(5 \mu \mathrm{g} / \mathrm{ml}, 10 \mu \mathrm{g} / \mathrm{ml}, 15 \mu \mathrm{g} / \mathrm{ml}$, $20 \mu \mathrm{g} / \mathrm{ml}$ and $25 \mu \mathrm{g} / \mathrm{ml})$. Methanolic extracts of four plant extracts were used. Baccaurea leaves, Scoparia leaves, Curculigo roots extracts did not show any cytotoxic activity in any of those five different concentrations. Only Pandans fascicularis extracts showed cytotoxicity in a dose dependent manner (Table 3). From the percentage (\%) lethality of brine-shrimp, probit analyses were carried out by probit analysis software (Fig. 3). From the dose value, lethal concentration 50 or $\mathrm{LC}_{50}$ value were calculated. $\mathrm{LC}_{50}$ value of $P$. fascicularis root of methanolic extract was found $25.64 \mu \mathrm{g} / \mathrm{ml}$ with $95 \%$ confidence limits. The results suggest that the $P$. fascicularis root extract is highly toxic to cells at least against brine-shrimp larvae.

Aqueous and methanolic extracts of the four plant extracts were used for the qualitative analysis of the four plant extracts. Baccaurea leaves showed positive results for the test of presence for glycosides, carbohydrate, steroids, phenolic compound and phytosterols but negative the presence of protein, alkaloid, tannin, phlobatannin, flavonoid, saponine, fats and anthraquinones for both the aqueous and methanolic extracts. 
Table 2. Qualitative analysis of the phytochemical screening of aqueous and methanolic extracts of four medicinally important plant samples from Bangladesh. Here, "+" refers to presence and "-" refers to absence.

\begin{tabular}{|c|c|c|c|c|c|c|c|c|}
\hline \multirow[b]{2}{*}{ Compound name } & \multicolumn{2}{|c|}{ B. sapida (leaf) } & \multicolumn{2}{|c|}{ P. fascicularis (root) } & \multicolumn{2}{|c|}{ C. orchioides (root) } & \multicolumn{2}{|c|}{ S. dulcis (leaf) } \\
\hline & $\begin{array}{l}\text { Aqueous } \\
\text { extract }\end{array}$ & $\begin{array}{l}\text { Methanolic } \\
\text { extract }\end{array}$ & $\begin{array}{l}\text { Aqueous } \\
\text { extract }\end{array}$ & $\begin{array}{l}\text { Methanolic } \\
\text { extract }\end{array}$ & $\begin{array}{l}\text { Aqueous } \\
\text { extract }\end{array}$ & $\begin{array}{c}\text { Methanolic } \\
\text { extract }\end{array}$ & $\begin{array}{l}\text { Aqueous } \\
\text { extract }\end{array}$ & $\begin{array}{c}\text { Methanolic } \\
\text { extract }\end{array}$ \\
\hline $\begin{array}{l}\text { Fehling's test for } \\
\text { glycosides }\end{array}$ & + & + & - & - & + & - & + & - \\
\hline $\begin{array}{l}\text { General test for } \\
\text { glycosides }\end{array}$ & + & + & - & & + & & - & \\
\hline $\begin{array}{l}\text { Biuret test for } \\
\text { protein }\end{array}$ & - & - & + & - & - & - & + & - \\
\hline $\begin{array}{l}\text { Benedict's test for } \\
\text { simple } \\
\text { carbohydrate }\end{array}$ & + & + & + & + & + & + & + & + \\
\hline $\begin{array}{l}\text { Hager reagent for } \\
\text { alkaloid test }\end{array}$ & - & - & - & + & - & + & - & + \\
\hline $\begin{array}{l}\text { Ferric chloride test } \\
\quad \text { for tannin }\end{array}$ & - & - & + & - & + & + & - & - \\
\hline $\begin{array}{c}\text { Test for } \\
\text { phlobatannin }\end{array}$ & - & - & - & - & - & + & - & - \\
\hline $\begin{array}{l}\mathrm{HCl} \text { test for } \\
\text { flavonoid }\end{array}$ & - & - & + & - & - & - & - & - \\
\hline $\begin{array}{l}\text { Salkowski's test for } \\
\text { steroids }\end{array}$ & + & + & + & & - & & - & \\
\hline $\begin{array}{l}\text { Frothing test for } \\
\text { saponine }\end{array}$ & - & - & - & & - & - & + & - \\
\hline $\begin{array}{l}\text { Test for phenolic } \\
\text { compound }\end{array}$ & + & + & + & + & + & + & - & - \\
\hline $\begin{array}{c}\text { Test for } \\
\text { phytosterols }\end{array}$ & + & + & - & & - & & + & \\
\hline $\begin{array}{l}\text { Ethanol emulsion } \\
\text { test for fats }\end{array}$ & - & - & - & & - & - & + & - \\
\hline $\begin{array}{c}\text { Test for } \\
\text { Anthraquinones }\end{array}$ & - & - & - & & - & & - & \\
\hline
\end{tabular}

In case of Pandans fascicularis root extracts, for both aqueous and methanolic extracts negative result was found for the test of presence for glycosides, phlobatannin whereas the test of presence for carbohydrate was positive. In case of test of presence for protein, tannin and flavonoid, the aqueous extracts showed positive but methanolic extracts showed opposite. Negative results were found for the aqueous extracts of the test of presence for saponine, phytosterols, fats and anthraquinones.

Curculigo roots showed positive results for both the extracts for the test of presence of carbohydrate, tannin and phenolic compounds but negative for the protein, flavonoid, saponine and fat. The aqueous extracts of the Curculigo roots contains glycosides but not the alkaloid, phlobatannin, steroids, phytosterols and anthraquinones. Only the methanolic extracts of the Curculigo roots contain the alkaloid and phlobatannin. 
The aqueous extracts of Scoparia leaves showed positive results for the test of presence for glycosides, protein, carbohydrate, saponine, phytosterols and fats but negative results for the general test for glycosides, alkaloid, steroids and anthraquinones. On the other hand, the methanolic extracts of the roots indicated negative results for the presence of glycosides, protein, tannin, phlobatannin, flavonoid, saponine, phenol and fats but positive for carbohydrates and alkaloids.

Table 3. Brine-shrimp cytotoxicity of the methanolic extract of $P$. fascicularis root.

\begin{tabular}{ccccccccccc}
\hline $\begin{array}{c}\text { Dose } \\
\mu \mathrm{g} / \mathrm{ml}\end{array}$ & Log dose & Number & Kill & \%kill & Corr\% & $\begin{array}{c}\text { Emp } \\
\text { probit }\end{array}$ & $\begin{array}{c}\text { Expt } \\
\text { probit }\end{array}$ & Work probit & Weight & Final probit \\
\hline 5 & 0.6989628 & 10 & 1 & 10 & 10 & 3.72 & 3.343838 & 3.89 & 2.08 & 3.328856 \\
10 & 0.9999897 & 10 & 0 & 0 & 0 & 0 & 4.042734 & 3.34 & 4.390001 & 4.037427 \\
15 & 1.176079 & 10 & 4 & 40 & 40 & 4.75 & 4.451563 & 4.78 & 5.580001 & 4.451915 \\
20 & 1.301017 & 10 & 4 & 40 & 40 & 4.75 & 4.741631 & 4.74 & 6.16 & 4.745999 \\
25 & 1.397926 & 10 & 5 & 50 & 50 & 5 & 4.966625 & 4.99 & 6.34 & 4.974107 \\
\hline
\end{tabular}

\section{Expt probit vs Log dose}

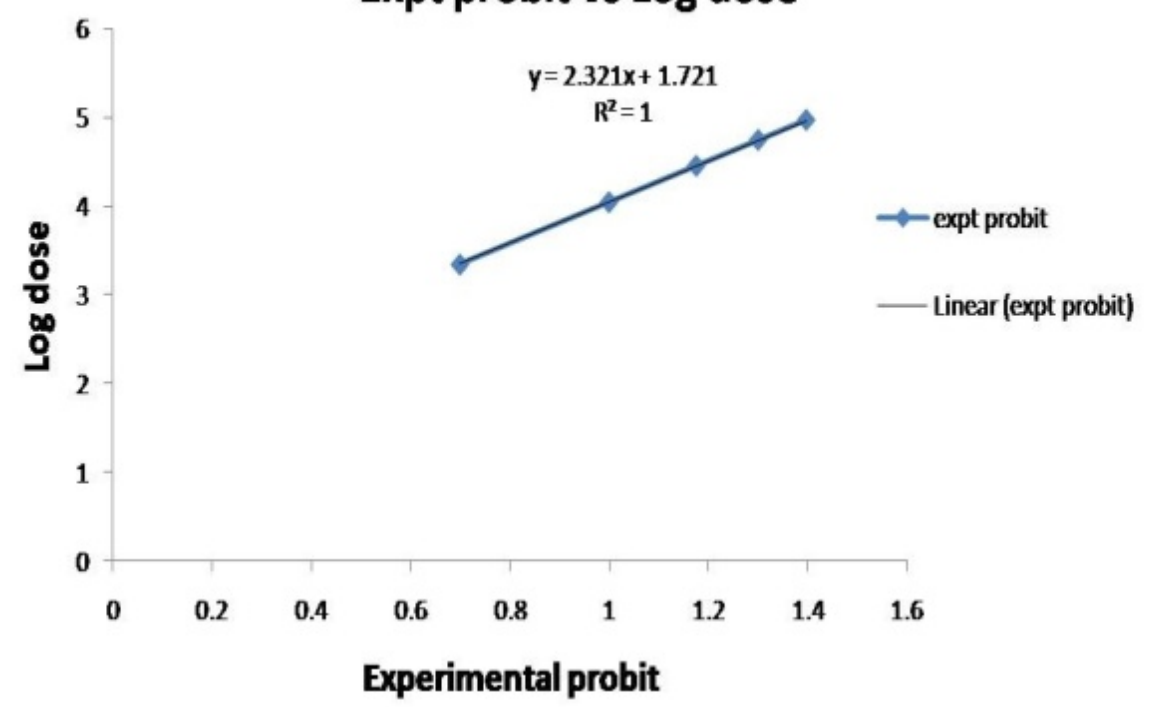

Fig. 3. Plot of $\log$ doses versus probit for calculation of $\mathrm{LC}_{50}$ of methanolic extract of $P$. fascicularis root. Finney's statistical method of probit analysis was used for the analysis of the data. 


\section{Conclusion}

The results of the study demonstrate that each of the four medicinally important plant extract has antioxidant activity where $P$. fascicularis and $S$. dulciss plant extract has highest antioxidant activity close to the standard ascorbic acid (positive control). So these plants are the significant source of natural antioxidant that can be used in cosmetic, food supplement, drug designing etc. From the phytochemical analysis, we found that each of these plant species possesses pharmacologically active biomolecules which may be the attribute of their folk medicinal use. From the result of preliminary cytotoxicity testing (Brine-shrimp lethality assay), only $P$. fascicularis extracts found to be the cytotoxic LD50 value of $P$. fascicularis root extract was found 25.64 $\mu \mathrm{g} / \mathrm{ml}$. Further biochemical investigations are in progress for purification and characterization of bioactive molecule present in the above described four medicinal plants.

\section{References}

Ahn K (2017). The worldwide trend of using botanical drugs and strategies for developing global drugs, BMB Reports 50(3): 111-116.

Alam M (2004). Indigenous agroforestry knowledge: Agro-economic studies on Latkan (Baccaurea sapida) production at Narsingdi District. MS Thesis, BSMR Agricultural University, Gazipur, Bangladesh.

Ayyanar M and Ignacimuthu S (2011). Ethnobotanical survey of medicinal plants commonly used by Kani tribals in Tirunelveli hills of Western Ghats, India, Journal of Ethnopharmacology 134(3): 851-864.

Balick MJ and Cox PA (1996). Plants, people, and culture: the science of ethnobotany: Scientific American Library.

Benedict SR (1909). A reagent for the detection of reducing sugars, Journal of Biological Chemistry 5(5): 485-487.

Chauhan NS, Sharma V, Thakur M and Dixit VK (2010). Curculigo orchioides: the black gold with numerous health benefits, Journal of Chinese Integrative Medicine 8(7): 613-623.

Chauhan N, Rao CV and Dixit V (2007). Effect of Curculigo orchioides rhizomes on sexual behaviour of male rats, Fitoterapia 78(7-8): 530-534.

Deb P and Bhowmick N (2013). Physico-chemical properties of burmese grape (Baccaurea sapida Muell. Arg.)-An underutilized fruit crop of West Bengal, International Journal of Agriculture and Food Science Technology 4(5): 415420.

Duraipandiyan V, Ayyanar M and Ignacimuthu S (2006). Antimicrobial activity of some ethnomedicinal plants used by Paliyar tribe from Tamil Nadu, India, BMC Complementary and Alternative Medicine 6(1): 35-42.

Edeoga H, Okwu D and Mbaebie B (2005). Phytochemical constituents of some Nigerian medicinal plants. African Journal of Biotechnology 4(7): 685-688.

Ghani A (1998). Medicinal plants of Bangladesh: chemical constituents and uses, Asiatic Society of Bangladesh.

Gornall AG, Bardawill CJ and David MM (1949). Determination of serum proteins by means of the biuret reaction, Journal of Biological Chemistry 177(2): 751-766.

Harvey AL (2008). Natural products in drug discovery, Drug Discovery Today 13(19): 894-901.

Hatano T, Kagawa H, Yasuhara T and Okuda T (1988). Two new flavonoids and other constituents in licorice root: their relative astringency and radical scavenging effects, Chemical and Pharmaceutical Bulletin 36(6): 2090-2097.

Igoli J, Ogaji O, Tor-Ayiin T and Igoli N (2006). Traditional medicine practice amongst the Igede people of Nigeria. Part II. African Journal of Traditional, Complementary and Alternative Medicines 2(2): 134-152.

Jain S (1986). Ethnobotany, Interdisciplinary Science Reviews 11(3): 285-292. 
Madhavan V, Nagar J C, Murali A, Mythreyi R and Yoganarasimhan S (2008). Antihyperglycemic activity of alcohol and aqueous extracts of Pandanus fascicularis lam. roots in alloxan induced diabetic rats, Pharmacologyonline 3: 529536.

Mann S, Satpathy G and Gupta R (2016). Evaluation of nutritional and phytochemical profiling of Baccaurea ramiflora Lour. syn. Baccaurea sapida, International Journal of Traditional Knowledge 15(1): 135-142.

Meyer B, Ferrigni N, Putnam J, Jacobsen L, Nichols DJ and McLaughlin JL (1982). Brine shrimp: a convenient general bioassay for active plant constituents, Planta Medica 45(05): 31-34.

Mollik MAH, Hossan MS, Paul AK, Rahman TU, Jahan R and Rahmatullah M (2010). A comparative analysis of medicinal plants used by folk medicinal healers in three districts of Bangladesh and inquiry as to mode of selection of medicinal plants, Ethnobotany Research and Applications 8: 195-218.

Nishat A, Huq SI, Barua SP, Reza A and Khan AM (2002). Bio-ecological zones of Bangladesh, IUCN Bangladesh Country Office, Dhaka, 1-141 pp.

Obadoni B and Ochuko P (2002). Phytochemical studies and comparative efficacy of the crude extracts of some haemostatic plants in Edo and Delta States of Nigeria, Global Journal of Pure and Applied Sciences 8(2): 203-208.

Pal R K, Bhowmick N and Suresh C (2008). Latka (Baccaurea sapida)-An under exploited minor fruit crop of West Bengal, Proceedings of the $3^{\text {rd }}$ Indian horticulture congress, new R and D initiatives in horticulture for accelerated growth and prosperity, 6-9 November 2008 held at QUAT Bhubaneswar, Organized by Horticulture Society of India, $325 \mathrm{pp}$.

Pant DR, Pant ND, Saru DB, Yadav UN and Khanal DP (2017). Phytochemical screening and study of antioxidant, antimicrobial, antidiabetic, anti-inflammatory and analgesic activities of extracts from stem wood of Pterocarpus marsupium Roxburgh, Journal of Intercultural Ethnopharmacology 6(2): 170-176.

Rajeswari J, Kesavan K and Jayakar B (2011). Phytochemical and pharmacological evaluation of prop roots of Pandanus fascicularis Lam, Asian Pacific Journal of Tropical Medicine 4(8): 649-653.

Rajeswari J, Kesavan K and Jayakar B (2012). Antidiabetic activity and chemical characterization of aqueous/ethanol prop roots extracts of Pandanus fascicularis Lam in streptozotocin-induced diabetic rats, Asian Pacific Journal of Tropical Biomedicine 2(1): 170-174.

Rates SMK (2001). Plants as source of drugs, Toxicon 39(5): 603-613.

Samuelsson G (2009). Drugs of natural origin: A treatise of pharmacognosy: Stockholm, SE, Swedish Academy of Pharmaceutical Sciences, $590 \mathrm{pp}$.

Senguttuvan J, Paulsamy S and Karthika K (2014). Phytochemical analysis and evaluation of leaf and root parts of the medicinal herb, Hypochaeris radicata L. for in vitro antioxidant activities, Asian Pacific Journal of Tropical Biomedicine 4: 359-367.

Sharmin L (2004). Cultivation prospect of medicinal plants in Bangladesh: experiences from Natore, BRAC-Research and Evaluation Division Dhaka, Bangladesh.

Smith-Hall C, Larsen HO and Pouliot M (2012). People, plants and health: a conceptual framework for assessing changes in medicinal plant consumption, Journal of Ethnobiology and Ethnomedicine 8(1): 43-54.

WHO (2000). Obesity: preventing and managing the global epidemic. http:// www.who.int/nutrition/publications /obesity/WHO_TRS_894/en/ 
Rashid et al. 